logos_i_ethos_2019_1_(49), s. 221-233

DOI: http://dx.doi.org/10.15633/lie.3443

Izabela Tomala

https://orcid.org/0000-0002-5861-0691

Uniwersytet Papieski Jana Pawła II w Krakowie

\title{
Uczciwość i rzetelność w zawodzie prawnika
}

Zarówno uczciwość, jak i rzetelność są niezwykle istotnymi zasadami, zgodnie z którymi prawnicy powinni wykonywać swoje zawodowe obowiązki. Bardzo trudno jest jednoznacznie zdefiniować, czym jest uczciwość i rzetelność w życiu zawodowym prawników. Mimo
Izabela Tomala - doktorantka Wydziału Filozoficznego UPJPII w Krakowie w Katedrze Filozofii Społecznej i Polityki. Jej zainteresowania oscylują wokół dylematów etyczno-prawnych współczesnego społeczeństwa. Wielokrotna stypendystka programu Erasmus+ przygotowująca rozprawę doktorską na temat współczesnego włoskiego filozofa Giorgia Agambena.

że z łatwością można stwierdzić, czym jest nieuczciwość i nierzetelność, to gdy należy przybliżyć definicję uczciwości i rzetelności, pojawiają się zasadnicze problemy.

W poniższej pracy zostanie podjęta próba ukazania tego, czym powinna być uczciwość i rzetelność w życiu zawodowym prawników. Obraz rzetelnego i uczciwego prawnika zostanie przedstawiony w oparciu o zagadnienia zarówno prawnicze, jak i filozoficzne. W pracy nie będzie rozróżnienia na poszczególne zawody prawnicze, gdyż po przeanalizowaniu większości kodeksów etyki zawodowej zawodów prawniczych, tj. Kodeksu etyki adwokackiej ${ }^{1}$, Kodeksu etyki zawodowej

1 Uchwała nr 52/2011 NRA z 19 listopada 2011 r., Zbiór zasad etyki adwokackiej i godności zawodu (Kodeks etyki adwokackiej). 
komornika sądowego ${ }^{2}$, Kodeksu etyki zawodowej notariusza ${ }^{3}$, Zbioru zasad etyki zawodowej sędziów ${ }^{4}$, zaobserwowano, że zarówno uczciwość, jak i rzetelność umieszczane są w każdym z ww. aktów jako jedne z najważniejszych cech dobrego adwokata, komornika, notariusza, sędziego. W związku z tym, gdy w poniższej pracy mowa o uczciwości i rzetelności prawników, należy to rozumieć jako uczciwość i rzetelność adwokata, komornika, notariusza, sędziego. Oczywiste jest, że zarówno uczciwość, jak i rzetelność w każdym z ww. zawodów prawniczych będzie objawiać się w innych zachowaniach, jednak, co istotne dla rozważań niniejszej pracy, uczciwość i rzetelność w zawodach prawniczych są fundamentem każdej profesji prawniczej.

\section{Uczciwość w zawodzie prawnika}

Czym zatem jest uczciwość w zawodach prawniczych? Poszukując odpowiedzi na to pytanie, należy sięgnąć do poszczególnych kodeksów etyki zawodowej, aby utwierdzić się jedynie w tym, że żaden spośród nich nie zawiera jednoznacznej definicji uczciwości. Po przekonaniu się, że polski ustawodawca oraz twórcy kodeksów etyki zawodowej poszczególnych zawodów prawniczych posługują się pojęciami niezdefiniowanymi, licząc na intuicję odbiorcy, która zgodnie z definicją zawartą w Słowniku języka polskiego jest niczym innym, jak „niezbyt umotywowanym, ale prawdopodobnym sądem o czymś” ${ }^{5}$, należy szukać pomocy w filozofii. Pomoc, niestety, może nie nadejść. Encyklopedia powszechna filozofii na temat uczciwości milczy jak zaklęta. Czyżby jej autorzy również liczyli na intuicję, która z kolei w filozofii oznacza „poznanie bezpośrednie, irracjonalne, polegające na uchwyceniu prawdy

2 Kodeks etyki zawodowej komornika sądowego, załącznik do uchwały KRK nr 909/IV z dnia 8 lutego 2012.

3 Uchwała Nr 19 Krajowej Rady Notarialnej z dnia 12 grudnia 1997 r., Kodeks etyki zawodowej notariusza.

4 Uchwała NR 16/2003 Krajowej Rady Sądownictwa z dnia 19 lutego 2003 r. w sprawie uchwalenia zbioru zasad etyki zawodowej sędziów.

${ }^{5}$ Słownik języka polskiego, http://sjp.pl/intuicja (25.01.2017). 
dzięki wewnętrznemu przekonaniu, bez pomocy rozumowania lub doświadczenia"? ${ }^{6}$ Niewprawny poszukiwacz prawdy mógłby w tym momencie zarzucić chęć odkrycia tego, czym tak naprawdę jest uczciwości, i napisałby, parafrazując św. Augustyna: „Czymże więc jest uczciwość? Jeśli nikt mnie o to nie pyta, wiem. Jeśli pytającemu usiłuję wytłumaczyć, nie wiem"7.

Nie można jednak tak szybko porzucać nadziei na odnalezienie definicji uczciwości. Zgodnie z myślą przypisywaną Gottfriedowi Wilhelmowi Leibnizowi „Dlatego, że nie znajdujemy, czego szukamy, nie powinniśmy rezygnować z szukania tego, co znaleźć możemy". W związku z tym warto sięgnąć do Małego słownika etycznego, w którym można znaleźć definicję uczciwości.

Uczciwość - zachowanie uznanych norm moralnych oraz rzetelne ich spełnianie ${ }^{8}$.

Powstaje jednak zasadnicze pytanie: przez kogo normy moralne, o których wspomina Mały słownik etyczny, mają być uznane. Czy mają mieć powszechną aprobatę czy wystarczy tylko indywidualna? Zgodnie $\mathrm{z}$ definicją zaproponowaną przez Tadeusza Ślipkę

[...] norma moralna jest to stałe zarządzenie kompetentnego autorytetu, uzdalniające podmioty rozumne (osoby fizyczne i moralne, czyli grupy) do działania etycznie godziwego'.

W związku z tym normy moralne, o których mowa w definicji uczciwości zawartej w Małym słowniku etycznym, to normy uznane przez odpowiedni, kompetentny autorytet. Ślipko w dalszej części swojej książki precyzuje, kogo należy uznać za „kompetentny autorytet”. Takim autorytetem może być prawodawca, który zgodnie z obowiązującym prawem

6 Słownik języka polskiego, http://sjp.pl/intuicja (25.01.2017).

7 Św. Augustyn, Wyznania, tłum. Z. Kubiak, Warszawa 1978, s. 227, Augustyn wypowiada się o czasie.

8 Św. Augustyn, Wyznania, dz. cyt., s. 227, Augustyn wypowiada się o czasie.

9 T. Ślipko, Zarys etyki ogólnej, Kraków 1974, s. 317. 
ustanawia imperatywy, do przestrzegania których zobowiązany jest podległy mu podmiot ${ }^{10}$. Nie należy jednak utożsamiać autorytetu, który ustanawia określone normy moralne, wyłącznie z prawodawcą w sensie prawnym, gdyż autorytet moralny może występować poza porządkiem prawnym.

Powstaje jednak pytanie: czym są owe powszechnie uznane normy moralne. Z pomocą przychodzi Maria Ossowska, która w swojej książce Normy moralne. Próba systematyzacji ${ }^{11}$ przeprowadza dokładną klasyfikację norm moralnych, wyróżniając m.in. normę godności, prywatności, sprawiedliwości, niezależności. Dzięki pracy Ossowskiej definicja uczciwości staje się nieco bardziej klarowna. Uczciwe działanie to takie działanie, podczas którego przestrzegane są ww. normy.

Za uczciwe postępowanie prawników należy zatem uznać takie działanie, które polega na wykonywaniu zawodowych obowiązków zgodnie $\mathrm{z}$ powszechnie znanymi i uznanymi normami moralnymi. Oznacza to, że uczciwy prawnik to taki prawnik, który wykonując swoje zawodowe obowiązki, przestrzega m.in. zasady godności, sprawiedliwości, równości itd.

Warto zwrócić uwagę, że wymienione przez Ossowską normy moralne są w większości normami, które zostały zawarte w Konstytucji RP ${ }^{12}$. Należy wspomnieć chociażby art. 30, mówiący o godności człowieka, art. 47 zawierający imperatyw ochrony życia prywatnego czy art. 2, w którym mowa jest o tym, że RP jest państwem urzeczywistniającym zasady sprawiedliwości społecznej. W związku z tym można stwierdzić, że uczciwy prawnik to taki prawnik, który działa zgodnie z powszechnie obowiązującym prawem, gdyż jak wykazała powyższa analiza, normy moralne w większości pokrywają się z zasadami zawartymi w powszechnie obowiązujących aktach prawnych.

Oczywiście nie zawsze jest tak, że normy moralne mają swoje odzwierciedlenie w obowiązującym prawie. Jednak zagadnienie dotyczące

10 T. Ślipko, Zarys etyki ogólnej, dz. cyt., s. 317.

11 M. Ossowska, Normy moralne. Próba systematyzacji, Warszawa 2000.

12 Ustawa z dnia 2 kwietnia 1997 r. Konstytucja RP (Dz.U. z dnia 16 lipca 1997 r. Nr 78, poz. 483) [dalej: Konstytucja RP]. 
różnic pomiędzy prawem a moralnością nie jest tematem niniejszej pracy.

Kim zatem powinien być uczciwy prawnik? Jak powinien zachowywać się uczciwy prawnik? Czy uczciwy prawnik powinien przestrzegać wyłącznie prawa stanowionego czy w zawodowym postępowaniu powinien odwoływać się również do norm moralnych? Które normy powinny być przestrzegane w pierwszej kolejności: prawne czy moralne? Postawienie powyższych pytań oraz próba udzielenia na nie odpowiedzi jest jednym z celów niniejszej pracy. Dzięki temu będzie można ukazać, jakie zachowania są właściwe i zasługują na promocję, a jakich należy się wystrzegać. Należy jednak mieć na uwadze to, że obszar powinności w wielu przypadkach odbiega od rzeczywistego stanu.

Na uczciwość prawnika składa się kilka etapów jej realizacji, dopiero bycie uczciwym na każdym z nich, może dać pełny obraz uczciwości prawniczej.

Pierwszą z uczciwości prawniczych można nazwać uczciwością charakterologiczną. Jest to uczciwość rozumiana jako trwała cecha charakteru danej osoby, czyli skłonność do uczciwego postępowania zarówno w sferze prywatnej, jak i zawodowej. Uczciwość charakterologiczną należy wypracować poprzez wykonywanie odpowiednich czynności, ćwiczenie się w uczciwym postępowaniu, czyli postępowaniu zgodnym z zasadami moralnymi i prawnymi. Roman Tokarczyk w książce Etyka prawnicza $a^{13}$ błędnie stwierdza, że uczciwe życie to otaczanie się uczciwymi osobami. Gdyby tak było, to prawnicy, którzy w wielu przypadkach stykają się z nieuczciwymi osobami (złodziejami, mordercami, oszustami), stawaliby się automatycznie osobami nieuczciwymi. Co więcej, samo otaczanie się uczciwymi osobami nie wpływa na poziom uczciwości danego prawnika. Oczywiście posiadanie wokół siebie uczciwych osób, o nieposzlakowanej opinii jest wskazane, jednak nie zawsze możliwe. Nie można przez pryzmat otoczenia, w jakim znajduje się dana jednostka, postrzegać jej samej. 
Uczciwość charakterologiczna przejawia się przede wszystkim w integralności danej osoby. Oznacza to, że dany prawnik swoim zachowaniem potwierdza swoje słowa. Uczciwy prawnik przestrzega wypracowanych norm nie tylko prawnych, ale i moralnych. W tym miejscu warto zadać pytanie, czy uczciwy zawodowo prawnik może być w życiu prywatnym nieuczciwym człowiekiem. Oczywiście że tak. Jednak cena, jaką może za ten brak integralności zapłacić, może być bardzo wysoka. Utrata zaufania klientów, korporacji zawodowych, społeczeństwa może doprowadzić do śmierci zawodowej danego prawnika. Co więcej, zarzut nieuczciwości raz postawiony danej osobie może wywołać nieodwracalne skutki wobec tej osoby. W związku z tym każdy prawnik powinien, jeżeli nie z osobistych przekonań, to z czysto utylitarnych pobudek odpowiedzieć sobie na pytanie: czy warto być nieuczciwym. Chwilowo może się to opłacić, jednak w perspektywie można wiele na tej nieuczciwości stracić.

$\mathrm{Na}$ uczciwość tego typu zwrócił uwagę również Roman Ingarden w książce Wykłady z etyki $i^{14}$. Obok uczciwości w potocznym znaczeniu tego słowa, wyróżnił on uczciwość wewnętrzną, którą charakteryzował jako uczciwość w odniesieniu do samego siebie, Boga oraz innych osób. Ta integralność, na którą zwrócił uwagę Ingarden, jest doskonałą ilustracją uczciwości charakterologicznej w życiu każdego prawnika.

Druga płaszczyzna uczciwości w zawodzie prawnika ujawnia się w konkretnych sytuacjach, stąd nazwa: uczciwość sytuacyjna. To właśnie podczas wykonywania zawodowych obowiązków obiektywny obserwator analizujący poszczególne decyzje danego prawnika mógłby wyciągnąć wnioski dotyczące jego uczciwości. Uczciwość sytuacyjna, jako dopełnienie uczciwości charakterologicznej, pokazuje, czy głoszone przez danego prawnika zasady, normy moralne i prawne mają odzwierciedlenie w rzeczywistości oraz jego czynach, czy są wyłącznie dobrze brzmiącymi frazesami. Tylko w konkretnych sytuacjach oraz poprzez konkretne zachowanie można dostrzec prawdziwe intencje danej osoby, danego prawnika. 
Za trzecią płaszczyznę, w której przejawia się uczciwość w tym zawodzie, należy uznać relację między prawnikiem a klientem. Jest to niezwykle ważna płaszczyzna. Uczciwy prawnik to taki, który w swoim postępowaniu nie wykorzystuje swojej silniejszej pozycji względem klienta. Prawnicy podczas wykonywania swoich zawodowych obowiązków obcują z najważniejszymi dobrami swoich klientów. Te dobra są zarówno materialne (pieniądze, nieruchomości), jak i niematerialne (dobre imię, wolność, zdrowie). Praca z tymi dobrami wymaga od prawnika pełnego zaangażowania oraz dużej delikatności. Uczciwie postępujący prawnik nigdy nie dopuści do tego, aby swoim zachowaniem narazić na uszczerbek jakiekolwiek dobra klienta. Uczciwy prawnik powinien dokładać należytej staranności, aby dobro klienta nie zostało naruszone. Niedopuszczalne jest wykorzystywanie przez prawników swojej mocniejszej pozycji w relacji profesjonalista - laik.

Czwarta płaszczyzna, w której ujawnia się uczciwość prawnika, to relacje koleżeńskie. W kodeksach etyki zawodowej zawodów prawniczych znajdują się informacje dotyczące tego, w jaki sposób należy zachowywać się $\mathrm{w}$ stosunkach prawnik-prawnik. Uczciwy prawnik to taki, który w relacjach koleżeńskich zachowa pełen profesjonalizm, będzie umiał komunikować się z drugim prawnikiem i mimo rozbieżnych interesów, nie będzie sięgał po niedozwolone metody w celu osiągnięcia przewagi nad drugą stroną sporu. Uczciwy prawnik nie wchodzi $\mathrm{w}$ nieprofesjonalne relacje $\mathrm{z}$ drugą stroną, nie stara się „załatwić" sprawy wbrew obowiązującym zasadom prawnym i moralnym.

Uczciwy prawnik to taki prawnik, który wykonując zawodowe obowiązki, jednoczy wszystkie ww. płaszczyzny uczciwości. Nie da się być uczciwym prawnikiem w sytuacji, gdy któraś z płaszczyzn uczciwości została pominięta. Uczciwy prawnik to ten, który głosząc zasady właściwego postępowania, żyje zgodnie z nimi, a nie wybiera tylko te, które przynoszą mu jakieś korzyści. Warto $\mathrm{w}$ tym miejscu wspomnieć słowa Jana Galarowicza, który w książce Powrót do wartości napisał: „Uczciwość to zgodność między myślą i słowem, mową i czynem, uczuciem i wyrażającym je gestem, postępowaniem a zasadami etycznymi, pieniądzem 
pożyczonym i pieniądzem oddanym"15. W taki właśnie sposób powinni postępować prawnicy, którzy chcieliby nosić miano uczciwych. Niestety, w dzisiejszym świecie uczciwość coraz częściej wypierana jest przez skuteczność. Wiele osób, korzystając z usług prawnika, wymaga od niego tego, aby przede wszystkim był skuteczny, natomiast uczciwość bywa pomijana. Presja społeczeństwa, otoczenia, przełożonych, zleceniodawców nigdy jednak nie powinna doprowadzić do tego, by wyznawane wartości przestały mieć znaczenie dla danej osoby, w tym wypadku prawnika.

\section{Rzetelność w zawodzie prawnika}

Rzetelność w zawodzie prawnika jest umiejętnością osiągnięcia arystotelesowskiego złotego środka pomiędzy nadgorliwością a niedbałym wykonywaniem zawodowych obowiązków. W kodeksach etyki zawodowej zawodów prawniczych rzetelność pojawia się jako synonim kompetencji, pilności, dokładności, dobrego przygotowania do wykonywania zawodowych obowiązków. Nie sposób mówić o rzetelności, nie wspominając o zagadnieniu profesjonalizmu prawniczego, który jest następstwem rzetelnej pracy.

Rzetelny prawnik to taki, który przede wszystkim zna i rozumie prawo zarówno krajowe, jak i międzynarodowe. Bez znajomości porządku prawnego danego kraju, a w obecnej sytuacji społeczno-politycznej także prawodawstwa Unii Europejskiej, współczesny prawnik nie może aspirować do miana rzetelnego. Raz zdobyta wiedza prawna nie jest jednak wystarczająca. Rzetelni prawnicy obowiązani są do stałego aktualizowania swojej wiedzy, gdyż w innym wypadku nie będą mogli właściwie wykonywać swoich zawodowych obowiązków.

Oprócz samej wiedzy teoretycznej, czyli znajomości prawa, rzetelny prawnik powinien pilnie i dokładnie przygotowywać się do wykonywania każdej powierzonej mu sprawy. Pilne przygotowanie oznacza poświęcenie odpowiedniej ilości czasu na zaznajomienie się z przedmiotem danego sporu, czyli wyjaśnienie niezrozumiałych kwestii,

15 J. Galarowicz, Powrót do wartości, Kraków 2011, s. 108-109. 
przeanalizowanie zebranego materiału, wyciągniecie odpowiednich wniosków. Rzetelny prawnik to osoba dokładna, która wykonując swoje zadania, korzysta $\mathrm{z}$ wielu dostępnych środków i metod, aby nikt nie zarzucił jej niedbalstwa.

Skąd pochodzi rzetelność prawników? Po przeanalizowaniu kodeksów etyki zawodowej zawodów prawniczych można stwierdzić, że źródłem rzetelności są normy moralne i prawne. Nie jest to jednak do końca zgodne z prawdą. To, że pojęcie rzetelności znajduje się w kodeksach, wskazuje jedynie na to, jak ważna jest owa rzetelność dla wszystkich zawodów prawniczych. Sama rzetelność powinna jednak mieć swoje źródło w danym prawniku, czyli bezpośrednio wypływać z jego samodyscypliny. Żadne zapisy kodeksowe, bez chęci wprowadzenia ich w życie nie przyniosą zakładanych efektów.

Nie można jednak w tym miejscu bagatelizować wartości istnienia kodeksów. Są one potrzebne do tego, aby wskazać, jakie wartości są istotne, i na jakie przy wykonywaniu zawodowych obowiązków należy zwrócić szczególną uwagę. Jak pisał Leszek Kołakowski:

Kodeks mówi [...], jakie wartości należy przedkładać nad inne; żaden kodeks nie jest naprawdę ostatecznie wyczerpujący, jednakże idea kodeksu zawiera w sobie dążność stałą do uzyskania ideału kompletności, a więc do takiego zbioru reguł, które dają się zastosować do dowolnej sytuacji moralnej i zawsze ją przesądzają jednoznacznie ${ }^{16}$.

To właśnie dzięki istnieniu kodeksów etyki zawodowej zawodów prawniczych prawnicy wiedzą, jakie wartości są ważne dla właściwego wykonywania zawodowych obowiązków i na co należy zwrócić szczególną uwagę. Normy zawarte w kodeksach są pewnego rodzaju drogowskazami, którymi powinni kierować się prawnicy przy wykonywaniu zawodowych obowiązków. Warto jednak zauważyć, że żaden prawnik korzystający z kodeksu nie może wyłączyć swojego krytycznego myślenia. Kodeksy mogą również zawierać błędy, a rzetelny prawnik, który

16 L. Kołakowski, Kultura i fetysze, Warszawa 2010, s. 155-156. 
właściwie wykonuje swoje zadania, w niejasnych sytuacjach powinien zwracać na takie błędy uwagę i dokładać wszelkiej staranności, aby je jak najskuteczniej wyeliminować.

Wrogiem rzetelności w wykonywaniu zawodowych obowiązków wśród prawników jest przede wszystkim pośpiech, a co za tym idzie niedbałe i niedokładne wykonywanie powierzonych zadań. Pośpiech i niedbalstwo w wielu sytuacjach doprowadzają do utraty dóbr materialnych i niematerialnych klienta danego prawnika. Klient, powierzając prawnikowi swoje dobra prawne, obdarza go zaufaniem i wierzy $\mathrm{w}$ to, że dany prawnik dołoży wszelkich starań, aby profesjonalnie reprezentować jego interesy.

Nie tylko pośpiech w wykonywaniu zawodowych obowiązków przeciwstawia się rzetelności. Jak pisał Paul d’Holbach:

istnieją przykłady spraw ciągnących się wiekami, a zjawiskiem zwyczajowym jest całkowita ruina procesujących się spowodowana bądź karygodną opieszałością sędziów, bądź nieuczciwością i podstępami prawników, bądź wreszcie wadami praw, które zbyt często zdają się być stworzone po to tylko, by wciągnąć obywateli w labirynt, z którego nie mogą się wydostać ${ }^{17}$.

Z powyższego fragmentu Etokracji wynika, że opieszałość oraz przewlekłość toczących się sporów (tak dobrze współcześnie znana) obnaża brak rzetelności i prawniczego profesjonalizmu. Warto zwrócić uwagę na to, jak trudno osiągnąć równowagę pomiędzy pośpiesznym i niedbałym rozwiązywaniem prawnych problemów a opieszałym i celowo wydłużanym procesowaniem się stron. Rzetelny prawnik powinien jednak ów złoty środek znaleźć i starać się go jak najdłużej utrzymać.

Tadeusz Kotarbiński w książce Medytacje o życiu godziwym ${ }^{18}$ pisał, że nie każdego stać na osiągnięcie mistrzostwa w tym, co robi, jednak każdy może wykonać wysiłek, który zmniejszy dystans pomiędzy daną osobą a osiągnięciem zamierzonego celu. Celem każdego prawnika

17 P. d'Holbach, Etokracja, Warszawa 1979, s. 60.

18 T. Kotarbiński, Medytacje o życiu godziwym, Warszawa 1989, s. 49-53. 
powinno być rzetelne wykonywanie zawodowych obowiązków. Dodatkowo Kotarbiński uważa, że przy wykonywaniu obowiązków należy pozbawić się marazmu, opieszałości, tandeciarstwa, partactwa czy fuszerki. Użycie tak dosadnego słownictwa pokazuje, jak ważne jest to, by $\mathrm{z}$ należytą starannością i rzetelnością wykonywać swoje zawodowe obowiązki.

Warto w tym miejscu zwrócić uwagę na to, że rzetelny prawnik to również rzetelny człowiek, który powinien $\mathrm{z}$ taką samą dokładnością wykonywać nie tylko zawodowe obowiązki, ale także i obowiązki dnia codziennego. Spójność w życiu zawodowym i prywatnym ukazuje, że wzniosłe słowa dotyczące rzetelności nie są jedynie pustymi frazesami, ale mają odzwierciedlenie w rzeczywistości.

Rzetelność to samodyscyplina, koncentracja, skupienie uwagi na konkretnym działaniu, to precyzyjne wykonywanie obowiązków.

Podsumowując tematykę uczciwości i rzetelności w zawodzie prawnika, należy zwrócić uwagę na to, że zarówno uczciwość, jak i rzetelność są zasadami, bez których żaden prawnik nie może się obyć. Niewyobrażalne jest właściwe wykonywanie zawodu prawnika przy jednoczesnym nieprzestrzeganiu zasady uczciwości i rzetelności. Dobry prawnik to uczciwy i rzetelny prawnik. Te dwie zasady bardzo dobrze się uzupełniają: tylko uczciwy prawnik będzie rzetelnie wykonywał powierzone mu obowiązki, tylko rzetelny prawnik będzie uczciwie realizował swoje zadania. Osoba nieuczciwa będzie dokładać wszelkich starań, aby to, co ma zrobić, realizować jak najmniejszym nakładem pracy, osiągając pozorny efekt dobrze wykonanego obowiązku.

\section{Bibliografia}

Galarowicz J., Powrót do wartości, Kraków 2011.

Holbach P. d', Etokracja, Warszawa 1979.

Ingarden R., Wykłady z etyki, Warszawa 1989.

Kodeks etyki zawodowej komornika sądowego, załącznik do uchwały KRK nr 909/IV $\mathrm{z}$ dnia 8 lutego 2012.

Kołakowski L., Kultura i fetysze, Warszawa 2010. 
Kotarbiński T., Medytacje o życiu godziwym, Warszawa 1989.

Ossowska M., Normy moralne. Próba systematyzacji, Warszawa 2000.

Słownik języka polskiego, http://sjp.pl/intuicja (25.01.2017).

Ślipko T., Zarys etyki ogólnej, Kraków 1974.

Św. Augustyn, Wyznania, tłum. Z. Kubiak, Warszawa 1978.

Tokarczyk R., Etyka prawnicza, Warszawa 2011.

Uchwała Nr 16/2003 Krajowej Rady Sądownictwa z dnia 19 lutego 2003 r. w sprawie uchwalenia zbioru zasad etyki zawodowej sędziów.

Uchwała Nr 19 Krajowej Rady Notarialnej z dnia 12 grudnia 1997 r., Kodeks etyki zawodowej notariusza.

Uchwała Nr 52/2011 NRA z 19 listopada 2011 r., Zbiór zasad etyki adwokackiej i godności zawodu (Kodeks etyki adwokackiej).

Ustawa z dnia 2 kwietnia 1997 r. Konstytucja RP (Dz. U. z 16 lipca 1997 r. Nr 78, poz. 483).

\section{Abstrakt}

\section{Uczciwość i rzetelność w zawodzie prawnika}

W poniższej pracy zostanie podjęta próba udzielenia odpowiedzi na pytanie, czym jest uczciwość i rzetelność w zawodzie prawnika oraz jakimi cechami powinien charakteryzować się uczciwy i rzetelny prawnik. Przy analizowaniu tych dwóch pojęć zostaną przedstawione odwołania do tekstów filozoficznych oraz kodeksów zawodowych zawodów prawniczych. W pracy wielokrotnie podkreślane jest to, że zarówno uczciwość, jak i rzetelność są zasadami, bez których prawnik nie może właściwie wykonywać swoich zawodowych obowiązków.

\section{Słowa kluczowe}

uczciwość, rzetelność, prawo, filozofia, etyka 


\section{Abstract}

\section{Honesty and reliability in the profession of lawyer}

In this paper the author will attempt to answer a question of what honesty and diligence mean in the profession of a lawyer, as well as what traits should be possessed by an honest and diligent lawyer. When analysing these two terms, references will be mad to philosophical texts and codes of practice for legal professions. It is repeatedly stressed in the paper that both honesty and diligence are principles without which lawyers can not properly per form their professional duties.

\section{Keywords}

honesty, diligence, law, philosophy, ethic 